\title{
PENGARUH MODEL ANALOGI BERBASIS ETNOSAINS UNTUK MENCEGAH KESALAHAN KONSEP SISWA
}

\author{
Nurlaili ${ }^{1)}$, dan Chairul Fuadi ${ }^{2)}$ \\ ${ }^{1), 2)}$ Program Studi Pendidikan Biologi STKIP Bina Bangsa Meulaboh, Aceh \\ email $^{1)}$ :nurlaili084@gmail.com
}

\begin{abstract}
ABSTRAK: Penelitian ini bertujuan untuk mengetahui pengaruh model pembelajaran analogi berbasis etnosains terhadap kemampuan pemecahan masalah siswa pada materi keanekaragaman hayati. Populasi dalam penelitian ini yaitu seluruh siswa-siswi kelas X SMA Negeri 1 Meureubo Kab. Aceh Barat. Sampel penelitian ini adalah siswa kelas X Mia ${ }_{2}$ dan $\mathrm{X} \mathrm{Mia}_{3}$ yang masing-masing berjumlah 20 siswa dengan keseluruhan 40 siswa. Siswa kelas $\mathrm{X} \mathrm{Mia} \mathrm{M}_{2}$ sebagai kelas kontrol dan X Mia 3 sebagai kelas eksperimen. Teknik pengambilan sampel menggunakan teknik random sampling. Penelitian ini menggunakan pendekatan penelitian kuantitatif dengan jenis penelitian eksperimen semu. Sedangkan desains penelitian yang digunakan adalah desain Pretest-Posttest Control Group Design. Data dalam penelitian ini di dapatkan dari hasil tes pretest dan postets dengan jumlah 20 soal pilihan ganda. Analisis data menggunakan analisis One Way ANOVA dengan program SPSS 18.0. Sebelum dilakukan uji One Way ANOVA, Data terlebih dahulu di uji Normalitas dan Homogenitas Data. Hasil penelitian menunjukkan bahwa kelas yang diberikan perlakuan dengan model pembelajaran analogi berbasis etnosains lebih baik dari pada kelas yang tidak diberikan perlakuan.
\end{abstract}

Kata Kunci: Model pembelajaran analogi, etnosasins, pemecahan masalah

ABSTRACT: The study aimed to identify the learning model etnosains analogy based on ability to problem solving students on biodiversity. Material The population in this research even all the class $\mathrm{x}$ SMAN 1 meureubo kabupaten. Aceh Barat. The sample is students and class X Mia 2 and X Mia 3 each were 20

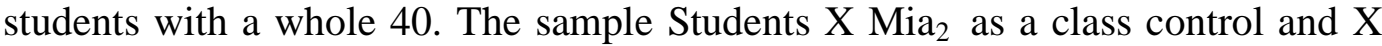
$\mathrm{Mia}_{3}$ experiment as a class. The sample collection technique using a technique random sampling This study used the quantitative research with the kind of research experiments. speciousWhile desains research used is design pretestposttest control group. designThe data in this study in found pretest postets and scores of double. 20 about choiceData analysis using analysis one way anova 18.0. spss programBefore undergone a one way anova, the first in the normality and homogeneity. dataThe result showed that given class treatment by analogy etnosains learning model based on class better than by treatment.

Keywords: Analogy learning model, etnosasins, solving

\section{PENDAHULUAN}

\begin{tabular}{lr}
\multicolumn{2}{c}{ Berhasilnya } \\
pembelajaran jika terjadinya \\
perubahan prilaku pada peserta didik
\end{tabular}

dari tidak tahu menjadi tahu. Pada umumnya keberhasilan proses belajar mengajar di sekolah ditentukan oleh guru. Karena guru 
merupakan suati individu yang menyelenggaraan proses pembelajaran dikelas. Lukum (2015) menyatakan bahwa tugas utama guru adalah menyelenggara pembelajaran dalam kelas sesuai dengan kurikulum dan silabus dengan tujuan mengubah pola pikir, sikap dan keterampilan siswa. Maka dari itu, guru senantiasa melakukan inovasi dalam proses pembelajaran dengan tujuan menciptakan susana belajar yang baik. Inovasi-inovasi tersebut dapat dilakukan terhadap model pembelajaran yang digunakan. Model pembeajaran merupakan serangkaian kegiatan proses pembelajaran dalam penyajian materi ajar yang memuat tugas atau aktivitas guru dan siswa serta mengatur segala fasilitas yang digunakan dalam proses pembelajaran.

Hasil Observasi di beberapa SMA di Aceh Barat menunjukkan bahwa umumnya guru-guru biologi sudah menggunakan model pembelajaran. Namun pemilihan model pembelajaran yang digunakan tidak melalui hasil evaluasi proses pembelajaran sehingga permasalahan peserta didik dalam proses belajar mengajar tidak dapat di atasi. Hasil observasi juga ditemui bahwa permasalahan siswa yang paling banyak muncul adalah kesalahan konsep, dimana siswa lebih cenderung mendefenisikan suatu konsep biologi sesuai dengan apa yang tertulis didalam buku paket. Hal ini jika terus menerus dibiarkan tanpa adanya usaha pencegahan akan mengakibatkan dampat negatif bagi kemajuan pendidikan. Selain dari itu, masalah dalam pembelajaran biologi dewasa ini adalah siswa hanya terpaku pada defenisi teori yang tertera dalam buku teks sehingga belum mampu mengkonstruk teori biologi menjadi defenisi baru. Siswa mengalami kesulitan dalam memecahkan masalah ke ranah kognitif, afektif, dan psikomotorik. Kesalahan siswa yang paling banyak muncul dalam pembelajaran biologi adalah pada proses. Hadi, K (2018) menyatakan bahwa pembelajaran disekolah masih kurang melatih dan mengembangkan kemampuan berpikir peserta didik sehingga berefek terhadap kemampuan berpikir peserta didik yang rendah.

Pencegahan terhadap kesalahan konsep siswa dapat dilakukan salah satunya dengan menggunakan model pembelajaran analogi. Model analogi merupakan model yang digunakan 
untuk mencegah miskonsepsi terhadap materi dan didalam proses belajar mengajar menggunakan analogi untuk menjelaskan konsep (Glynn, 2007). Proses pembelajaran analogi didasarkan pada imajinasi siswa (Walker, D. E. 2009). (Azmi, M. P (2015) mengungkapkan bahwa analogi merupakan kegiatan menarik kesimpulan sementara yang dilakukan dengan membandingkan kesamaan antara suatu konsep dengan konsep yang baru.

Pembelajaran biologi tidak terlepas dari kehidupan sehari-hari siswa. Hadi, K (2019) menyatakan bahwa Biologi sebagai bagian dari sains tidak terlepas dari kejadiankejadian yang dialami oleh suatu kalangan masyarakat disuatu daerah. Pembelajaran biologi bukan sekedar pengetahuan hal-hal yang bersifat fakta, konsep, atau prinsip. Melainkan mencari tahu mengenai alam secara terstruktur (sistematis). Maka dari itu, untuk mengaitkan ilmu pengetahuan dengan kehidupan siswa dapat diformulasikan dengan pembelajaran berbasis entosains. Atmojo (2012) menyatakan bahwa pembelajaran berbasis etnosain dapat memberikan danpak yang baik dimana siswa mengakui kekayaan budaya masyarakat sebagai bagian yang dasar dan perlu untuk dikaji sebagai penemuan gagasan dalam perkembangan pengetahuan.

Berdasarkan kajian diatas, perlu dilakukan penelitian untuk mencegah kesalahan konsep siswa melalui penggunaan model analogi berbasis etnosains.

\section{METODE PENELITIAN}

\section{Pendekatan dan Jenis Penelitian}

Pendekatan

kuantitatif merupakan pendekatan yang di gunakan dalam penelitian ini. Pendekatan kuantitatif digunakan dengan tujuan untuk mendapatkan sebuah kesimpulan dari pengaruh model pembelajaran analogi berbasis etnosains terhadap kesalahan konsep siswa. Jenis penelitian yang digunakan adalah eksperimen semu. Desain penelitian menggunakan Pretest-Posttest Control Group Design.

\begin{tabular}{lccc}
\hline $\begin{array}{l}\text { Kelas } \\
\text { Kontrol }\end{array}$ & $\mathrm{O}_{1}$ & 0 & $\mathrm{O}_{2}$ \\
\hline $\begin{array}{l}\text { Kelas } \\
\text { Eksperimen }\end{array}$ & $\mathrm{O}_{1}$ & $\mathrm{X}$ & $\mathrm{O}_{2}$ \\
\hline
\end{tabular}


Keterangan :

$\mathrm{O}_{1} \quad$ : Pretest

$\mathrm{O}_{2} \quad$ : Posttest

0 : Tanpa menggunakan model pembelajaran analogi berbasis etnosain X : Menggunakan Model pemebalajaran analogi berbasis etnosains

\section{Populasi dan Sampel}

Populasi dalam penelitan ini adalah siswa kelas X SMA Negeri 1 Meureubo Kabupaten Aceh Barat. Sampel dalam penelitian ini, yaitu kelas X Mia ${ }^{2}$ (kontrol) berjumlah 20 siswa dan $\mathrm{Mia}^{3}$ (eksperimen) yang berjumlah 20 siswa.. Pengambilan sampel dilakukan dengan teknik random sampling.

\section{Instrumen dan Teknik}

\section{Pengumpulan Data}

Instrumen dalam penelitian ini menggunakan soal tes pemahaman konsep pada materi keanekaragaman hayati. Soal tes dalam penelitian ini soal pilihan ganda dengan jumlah 20 soal. Soal tes diisi oleh siswa diawal (pretest) dan akhir proses pembelajaran (postest).

\section{Teknik Analisis data}

Analisis data menggunakan uji statistik sederhana dan uji statistik inferensial. Uji statistik sederhana dilakukan untuk menguji lembar observasi proses pembelajaran guru dan lembar respon siswa menggunakan uji nilai rata-rata. Sedangkan uji statistik inferensial menggunakan uji Anova satu jalur (one way ANOVA). Sebelum dilakukan uji Anova, dalam penelitian ini dilakukan terlebih dahulu uji prasyarat yaitu uji normalitas data (Shapiro-Wilk) dan homogenitas data (Test homogeneity of Variances). Analisis data dilakukan menggunakan SPSS 18.0.

Setelah analisis data dilakukan kemudian data diintepretasikan sebagai berikut.

Tabel 1. Intepretasi Data analisis uji Normalitas Data, Homogenitas Data, dan Uji Anova 1 Jalur

\begin{tabular}{llc}
\hline \multirow{2}{*}{ Uji Normalitas Data } & Sig. (2-tailed) $>\alpha 0,05$ & Normal \\
\cline { 2 - 3 } & Sig. (2-tailed) $<\alpha 0,05$ & Tidak Normal \\
\hline \multirow{2}{*}{ Uji Homogenitas Data } & Sig. (2-tailed) $>\alpha 0,05$ & Homogen \\
\cline { 2 - 3 } & Sig. (2-tailed) $<\alpha 0,05$ & Tidak Homogen \\
\hline
\end{tabular}


One Way Anova

Sig. (2-tailed) $>\alpha 0,05 \quad$ Tidak terdapat Perbedaan

Sig. (2-tailed) $<\alpha 0,05 \quad$ Terdapat perbedaan

3.HASIL DAN PEMBAHASAN eksperimen pretest Sig. $(0,363)>\alpha$

Tabel 2. Uji Normalitas data 0,05 ,dan kelas eksperimen posttest

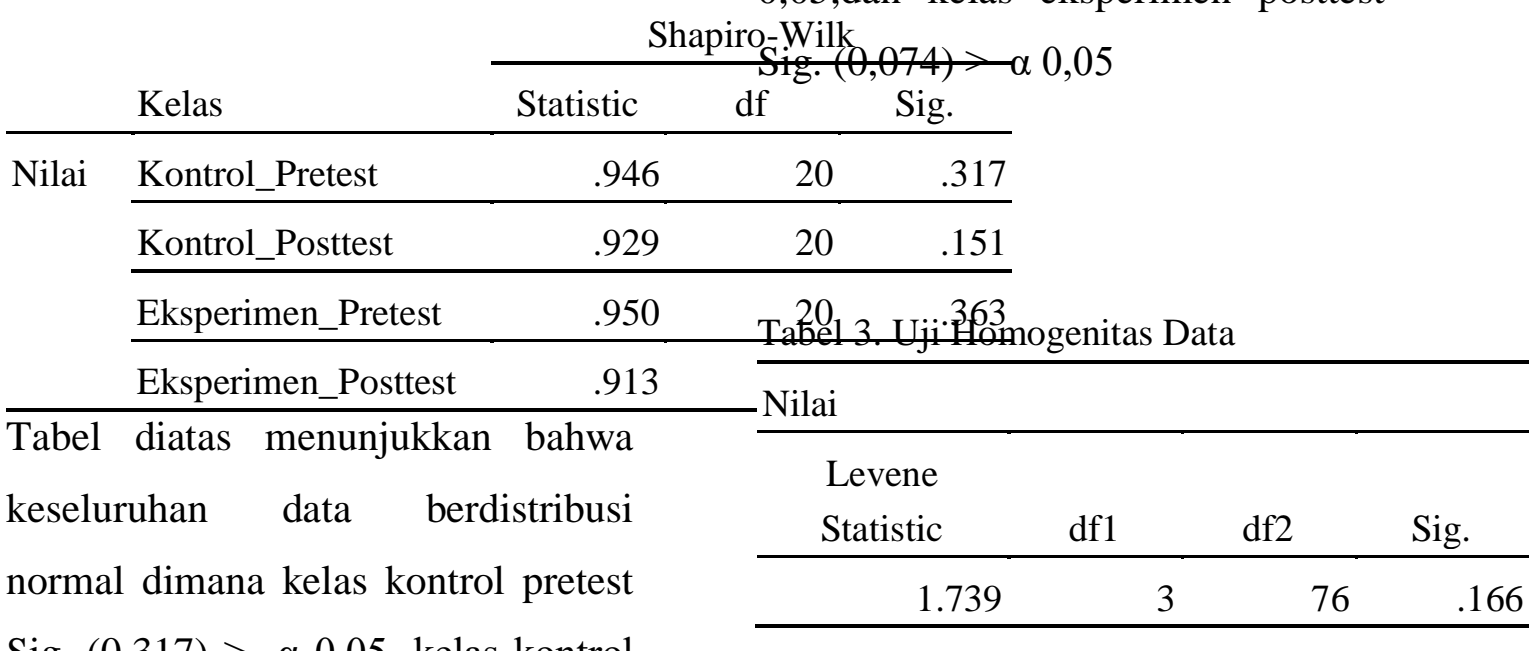

Sig. $(0,317)>\alpha 0,05$, kelas kontrol

posttest Sig. $(0,151)>\alpha 0,05$, Kelas

Tabel diatas menunjukkan bahwa

data homogen Sig. $(0,166)>\alpha 0,05$.

Tabel 4. Uji One Way Anova

Nilai

\begin{tabular}{lcrrrrr} 
& Sum of Squares & df & Mean Square & F & Sig. \\
\hline Between Groups & 24068.438 & 3 & 8022.812 & 79.926 & .000 \\
\hline Within Groups & 7628.750 & 76 & 100.378 & & \\
\hline Total & 31697.188 & 79 & & & \\
\hline Tabel di & dilaksanakan & pada penelitian ini
\end{tabular}

Tabel di atas diketahui terdapat

perbedaan nilai rata-rata hasil belajar dengan mengadopsi langkah-langkah siswa antara kelas kontrol (pretest dan posttest) dan kelas eksperimen (pretest dan posttest) dimana Sig. $(0,000)<\alpha 0,05$.

model pembelajaran analogi dan mengaitkan budaya (masalah keseharian siswa) pada materi keanekaragaman hayati. Langkahlangkah model analogi berbasis etnosains yang digunakan adalah

PEMBAHASAN

Proses pembelajaran model analogi berbasis etnosains yang 
Tabel 5. Rancangan Sintaks Pembelajaran menggunakan model analogi berbasis etnosains

\begin{tabular}{|c|c|c|}
\hline $\begin{array}{c}\text { Urutan Sintaks } \\
\text { Pembelajaran model } \\
\text { analogi berbasis } \\
\text { etnosains }\end{array}$ & Aktivitas Guru & Aktivitas Siswa \\
\hline $\begin{array}{l}\text { Tahap I } \\
\text { Mengkomunikasikan } \\
\text { topik atau materi } \\
\text { pembelajaran }\end{array}$ & $\begin{array}{l}\text { - Guru menjelaskan } \\
\text { tujuan mempelajari } \\
\text { keanekaragaman hayati } \\
\text { - Guru menjelaskan } \\
\text { pengertian } \\
\text { keanekaragaman } \\
\text { hayati, tingkat } \\
\text { keanekaragaman } \\
\text { hayati, dan pengaruh } \\
\text { aktivitas manusia } \\
\text { dalam keberlangsungan } \\
\text { kehidupan makhluk } \\
\text { hidup lainnya. }\end{array}$ & $\begin{array}{l}\text { Siswa mendengarkan } \\
\text { penjelasan dari guru }\end{array}$ \\
\hline $\begin{array}{l}\text { Tahap II } \\
\text { Penggabungan proses } \\
\text { analogi langsung, } \\
\text { perbandingan dan } \\
\text { penjelasan perbedaan }\end{array}$ & $\begin{array}{l}\text { Guru meminta siswa } \\
\text { mengajukan pendapat } \\
\text { mengenai materi yang } \\
\text { telah dijelaskan dan atau } \\
\text { dibahas }\end{array}$ & $\begin{array}{lr}\text { Siswa } & \text { mengajukan } \\
\text { pendapat } & \text { dan atau } \\
\text { pertanyaan } & \end{array}$ \\
\hline $\begin{array}{l}\text { Tahap III } \\
\text { Analogi personal }\end{array}$ & $\begin{array}{lr}\text { Guru memberi } & \text { tugas } \\
\text { individu } & \text { untuk } \\
\text { mempelajari } & \text { konsep } \\
\text { keanekaragaman } & \text { hayati, } \\
\text { tingkat keanekaragaman, } & \text { dan pengaruh aktivitas } \\
\text { manusia } & \text { dalam } \\
\text { keberlangsungan } & \\
\text { keanekaragaman hayati } \\
\text { seperti cara atau contoh } \\
\text { yang telah dijelaskan } \\
\text { guru }\end{array}$ & $\begin{array}{lr}\text { Siswa } & \text { mengerjakan } \\
\text { tugas secara } & \text { individu } \\
\text { melalui } & \text { berbagai } \\
\text { referensi } & \end{array}$ \\
\hline $\begin{array}{l}\text { Tahap IV } \\
\text { Eksplorasi (Pengamatan } \\
\text { secara berkelompok } \\
\text { keanekaragaman hayati } \\
\text { dilingkungan sekolah) }\end{array}$ & $\begin{array}{l}\text { Guru memberi tugas } \\
\text { secara kelompok untuk } \\
\text { mengamatii konsep } \\
\text { keanekaragaman hayati, } \\
\text { tingkat keanekaragaman, } \\
\text { dan pengaruh aktivitas } \\
\text { manusia dalam } \\
\text { keberlangsungan } \\
\text { keanekaragaman hayati } \\
\text { di lingkungan sekolah } \\
\text { seperti cara atau contoh } \\
\text { yang telah dijelaskan }\end{array}$ & $\begin{array}{l}\text { Siswa mengamati } \\
\text { keanekaragaman hayati } \\
\text { yang ada dilingkungan } \\
\text { sekolah }\end{array}$ \\
\hline
\end{tabular}




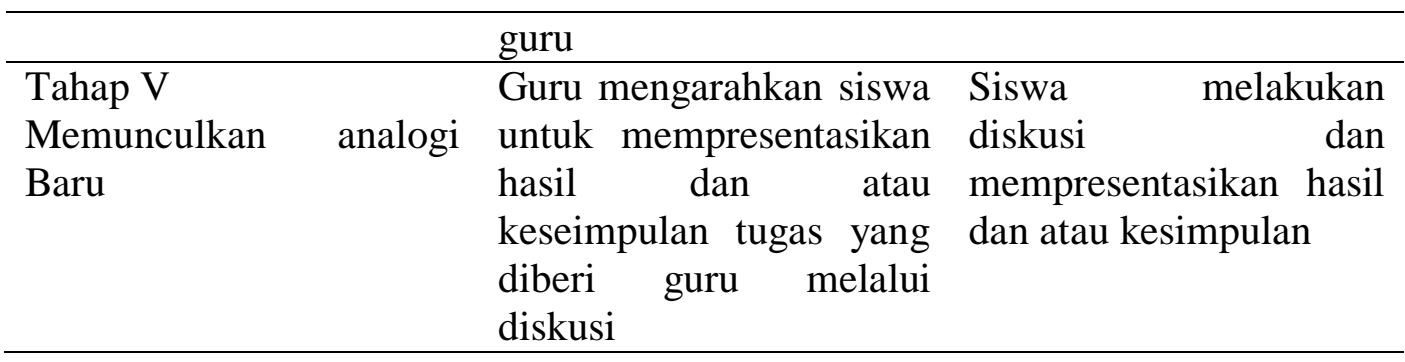

Hasil pembelajaran biologi pada materi keanekaragaman hayati menunjukkan bahwa siswa pada kelas kontrol diketahu nilai rata-rata pretest sebesar 45,50, dan posttest sebesar 72,50. Pada kelas eksperimen diketahui niliai pretes sebesar 44,25 dan posttest sebesar 84,50. Pada kelas kontrol peningkatan dari nilai rata-rata pretest ke posttest sebesar 27, sedangkan peningkatan kelas eksperimen dari nilai rata-rata pretest ke posttest sebesar 40.25. Ditinjau dari segi ketentusan minimal dengan nilai yang ditetapkan 70 maka diketahui pada kelas kontrol hanya $75 \%$ siswa yang dinyatakan tuntas dan sedangkan pada kelas eksperimen $100 \%$ siswa tuntas.

Pada umumnya peningkatan ketuntasan belajar siswa adalah karena siswa telah belajar tentang materi yang dilakukan tes. Sehingga siswa mampu menyelesaikan soal tes yang diberikan. Hasil analisis data menggunakan Uji One Way Anova diketahui bahwa terdapat perbedaan antara pretest dan postest kelas kontrol maupun kelas eksperimen. Namun perbedaan yang paling signifikan ditunjukkan pada nilai posttest kelas eksperimen. Hal ini dipengaruhi karena pada kelas eksperimen diberikan perlakuan khusus yaitu proses pembelajaran di ajarkan menggunakan model analogi berbasis etnosain. Hasil penelitian ini sejalan dengan hasil penelitian Ramdhayani, E., Ibrahim, M., \& Madlazim (2015) yang menyatakan bahwa penggunaan analogi dapat menghasilkan hasil beajar siswa baik.

Analogi merupakan sebuah alat bantu memori yang membantu siswa untuk mengingat konsep yang sulit sehingga akan berdampak pada meningkatnnya hasil belajar siswa (Treagust \& Venville, 1996). Di dukung juga oleh penelitian Kadir (2014) yang menyimpulkan bahwa analogi merupakan alat yang sangat baik untuk mengajarkan keterampilan berpikir agar dapat 
memahami konsep sains sehingga nantinya dapat meningkatkan hasil belajar kognitif siswa. Keberhasilan proses pembelajaran pada penelitian ini juga dipengaruhi oleh materi pembelajaran sesuai dengan lingkungan dan atau keseharian siswa yang disebut selanjutnya etnosains.

Etnosains yang diadopsi dalam penelitian ini mengarah pada pengertian etnosains yang diungkapkan oleh Erick Diggest yaitu belajar sains dari anggapan masyarakat dari kenyataan sekitar yang kemudian ditinjau kembali sesuai dengan bahasa yang berlaku disuatu lingkungan masyarakat. Etnosains yang diintegrasikan merupakan segala bentuk aktivitas masyarakat Aceh Barat dalam kehidupan sehari-hari yang telah menjadi budaya masyarakat Aceh Barat. Etnosains yang sesuai dengan materi keanekaragaman hayati yang digunakan dalam penelitian ini meliputi sumber kekayaaan laut, sumber kekayaan gunung, dan permasalahan lingkungan masyarakat. Siswa dapat kenal, sadar, dan mempelajari ilmu pengetahuan alam melalui pemanfaatan lingkungan sekitar (Novia, Nurjannah, \& Kamaluddin, 2015).

\section{KESIMPULAN DAN SARAN}

Kesimpulan dalam penelitian ini yaitu

1. terdapat perbedaan nilai ratarata hasil belajar siswa antara kelas kontrol (pretest dan posttest) dan kelas eksperimen (pretest dan posttest) dimana Sig. $(0,000)$ $<\alpha 0,05$.

2. Perbedaan yang signifikan ditunjukkan pada hasil belajar siswa kelas perlakuan dengan model pembelajaran analogi berbasis etnosains.

\section{DAFTAR PUSTAKA}

Azmi, M., P. 2015. Mengembangkan Kemampuan Analogi Matematis, (Jurnal Cendekia: Jurnal Pendidikan Matematika UIN Sultan Syarif Kasyim Riau , Volume 1 No 1), h. 102.

Atmojo. 2012. Profil Keterampilan Proses Sains dan Apresiasi Siswa Terhadap Profesi Pengrajin Tempe Dalam Pembelajaran IPA Berpendekatan Etnosains. Jurnal Pendidikan IPA Indonesia (JPII), 1(2): 115122 
Glynn, S. M. 2007. The teaching with analogies model. Science and Children, 44(8), 52-55

Hadi,K., et.al. 2019. Integration of Local Wisdom and Problem Based Learning Model in the Innovation of Biology Teaching Materials for Senior High School Students in Aceh - Indonesia. International Journal of Humanities Social Sciences and Education (IJHSSE), vol 6, no. 1, 2019, pp. 52-60. doi: http://dx.doi.org/10.20431/234 9-0381.0601006

Hadi, K. 2018. Pengembangan Model Problem Based Learning Berbasis Kearifan Lokal Pada Materi Keanekaragaman Hayati Kelas X Di Kabupaten Aceh Selatan. Jurnal Bionaatural olume 4 No 2 September. (42-52). ISSN 2355-3790.

Kadir. (2014). Merging Analogy and ICT as a Teaching Strategy to Enhance Students' Thinking Skill \& Understanding of Science Concept. Journal of Applied Sciences Research. Vol 10 No. 15, pp. 27-31.

Lukum, A. 2015. Evaluasi Program Pembelajaran IPA SMP Menggunakan Model Countenance STAKE. Jurnal penelitian dan evaluasi pendidikan, 19(1) : 25-37.

Novia, Nurjannah, \& Kamaluddin. 2015. Penalaran Kausal dan Analogi Berbasis Etnosains dalam Memecahkan Masalah Fisika. Prosiding Simposium Nasional Inovasi dan Pembelajaran Sains 2015 (SNIPS 2015), 8 dan 9 Juni
2015, Bandung, Indonesia. ISBN: 978-602-19655-8-0

Ramdhayani, E., Ibrahim, M., \& Madlazim. 2015.

Pembelajaran Sikap Melalui Analogi Dalam Mengajarkan Biologi. Jurnal Pendidikan Sains Pascasarjana Universitas Negeri Surabaya, Vol. 5, No. 1, ISSN : 20891776.

Treagust, D. F., Harrison, A. G., Venville, G. And Dagher, Z., (1996). Using an Analogical Teaching Approach to Engender Conceptual Change, International Journal of Science Education Vol. 18, 213-229

Walker, D. E. 2009. Promoting Metaphorical Thinking Through Synectics: Developing Deep Thinking Utilizing Abstractions. Advanced Active Learning. Bloomsburg University of Pennsylvania. 